\title{
Boron isotopic characterisation of serpentinites from the Atlin terrane, Canadian Cordillera: evidence for preserved oceanic core complexes?
}

\footnotetext{
A. BOGATU ${ }^{1}$, J.H. BÉDARD ${ }^{2}$, L. LABROUSSE ${ }^{3}$, C. MARTIN $^{4}$, A. TREMBLAY ${ }^{1}$, A. ZAGOREVSKI ${ }^{5}$

${ }^{1}$ UQAM, Montréal, QC, Canada (*correspondence : bogatu.adina@gmail.com; tremblay.a@uqam.ca) ${ }^{2}$ GSC, Québec, QC, Canada (jeanh.bedard@canada.ca) ${ }_{3}$ iSTeP, Pr Sorbonne Univ., UPMC Paris 06 (loic.labrousse@upmc.fr) ${ }^{4}$ American Museum of Natural History, New York, NY 10024-5102, USA (cmartin@amnh.org) ${ }^{5}$ GSC, Ottawa, ON, Canada (alex.zagorevski@canada.ca)

Ultramafic massifs from the Atlin (formerly Cache Creek) terrane, northern Canadian Cordillera, display an incomplete ophiolitic sequence as upper crustal rocks generally lie directly on mantle peridotites. Low-angle normal faults characterized by foliated serpentinites, rodingites and cataclasites mark the mantle-crust contact. Serpentinites from this contact at Union Mt. and Squanga Lake were investigated by microscopic petrography and Raman spectroscopy. Raman methods allow phase identification of different serpentine minerals: lizarditecrysotile $\left(0-300^{\circ} \mathrm{C} ;<1.0 \mathrm{GPa}\right)$ and antigorite $\left(300-460^{\circ} \mathrm{C}\right.$; higher-P). Boron isotopic compositions of serpentine minerals are representative of the fluids that altered the ultramafic rocks. Previous work showed that serpentine hydrated by seawater has $\delta^{11} \mathrm{~B}$ ranging from +40 to $+10 \%$, while serpentine hydrated by slab-derived metamorphic fluids has $\delta^{11} \mathrm{~B}$ ranging from +10 to $-6 \%$ (shallow fluids) or -6 to $-20 \%$ (deep fluids). At least three generations of serpentine minerals from the Atlin terrane were identified and analysed for $\delta^{11} \mathrm{~B}$ : 1) early lizarditechrysotile with $\delta^{11} \mathrm{~B}$ values of +13 to $-1 \%$; 2) a second generation of antigorite-chrysotile with $\delta^{11} \mathrm{~B}$ values of -2 to $-13 \%$; and 3) late antigorite flakes with $\delta^{11} \mathrm{~B}$ values of $+4 \%$ to $-2 \%$. Identification of several isotopically distinct serpentine generations support the hypothesis of: (1) early alteration of peridotites (early serpentine with $+\delta^{11} \mathrm{~B}$ ) by seawater-derived fluids, possibly associated with exhumation during oceanic core complex formation; (2) possible infiltration of aqueous fluids ( $2^{\text {nd }}$ generation of serpentine with strongly negative $\delta^{11} \mathrm{~B}$ ) during obduction and imbrication of ophiolite nappes; (3) re-exhumation (late antigorite flakes with $\delta^{11} \mathrm{~B}$ straddling $0 \%$ ), possibly reflecting late stages of obduction and thrust-stacking.
} 